\title{
Mutations in the voltage-gated sodium channel gene of anophelines and their association with resistance to pyrethroids - a review
}

\author{
Ana Paula B Silva', Joselita Maria M Santos ${ }^{1}$ and Ademir J Martins ${ }^{2,3^{*}}$
}

\begin{abstract}
Constant and extensive use of chemical insecticides has created a selection pressure and favored resistance development in many insect species worldwide. One of the most important pyrethroid resistance mechanisms is classified as target site insensitivity, due to conformational changes in the target site that impair a proper binding of the insecticide molecule. The voltage-gated sodium channel ( $\mathrm{Nav}$ ) is the target of pyrethroids and DDT insecticides, used to control insects of medical, agricultural and veterinary importance, such as anophelines. It has been reported that the presence of a few non-silent point mutations in the $\mathrm{Na}_{V}$ gene are associated with pyrethroid resistance, termed as ' $k d r$ ' (knockdown resistance) for preventing the knockdown effect of these insecticides. The presence of these mutations, as well as their effects, has been thoroughly studied in Anopheles mosquitoes. So far, kdr mutations have already been detected in at least 13 species (Anopheles gambiae, Anopheles arabiensis, Anopheles sinensis, Anopheles stephensi, Anopheles subpictus, Anopheles sacharovi, Anopheles culicifacies, Anopheles sundaicus, Anopheles aconitus, Anopheles vagus, Anopheles paraliae, Anopheles peditaeniatus and Anopheles albimanus) from populations of African, Asian and, more recently, American continents. Seven mutational variants (L1014F, L1014S, L1014C, L1014W, N1013S, N1575Y and V1010L) were described, with the highest prevalence of L1014F, which occurs at the 1014 site in Nav IIS6 domain. The increase of frequency and distribution of kdr mutations clearly shows the importance of this mechanism in the process of pyrethroid resistance. In this sense, several species-specific and highly sensitive methods have been designed in order to genotype individual mosquitoes for $k d r$ in large scale, which may serve as important tolls for monitoring the dynamics of pyrethroid resistance in natural populations. We also briefly discuss investigations concerning the course of Plasmodium infection in $k d r$ individuals. Considering the limitation of insecticides available for employment in public health campaigns and the absence of a vaccine able to brake the life cycle of the malaria parasites, the use of pyrethroids is likely to remain as the main strategy against mosquitoes by either indoor residual spraying (IR) and insecticide treated nets (ITN). Therefore, monitoring insecticide resistance programs is a crucial need in malaria endemic countries.
\end{abstract}

Keywords: Anopheles, Sodium channel, Malaria, Pyrethroids, Resistance, $k d r$

\section{Introduction}

The global situation of malaria and its vectors

Malaria is one of the most serious and complex health problems faced by humanity. Besides that, it has become a threat for social and economical development in tropical

\footnotetext{
* Correspondence: ademirj@@ioc.fiocruz.br

2Laboratório de Fisiologia e Controle de Artrópodes Vetores, Instituto

Oswaldo Cruz, FIOCRUZ, Rio de Janeiro, Brazil

${ }^{3}$ Instituto Nacional de Ciência e Tecnologia em Entomologia Molecular, Rio de Janeiro, Brazil

Full list of author information is available at the end of the article
}

and subtropical regions, specially given the decrease in work capacity of the affected victims [1]. According to the World Health Organization (WHO), approximately 207 million cases of malaria were reported in 2012, with an estimate of 627,000 deaths, with the highest incidence rates observed in Africa (80\%), Asia (15\%) and the Americas (14\%) [2]. Among the factors contributing to this scenario, it is possible to highlight the absence of an effective antimalarial vaccine, the distribution of drug-resistant Plasmodium, the development of insecticide resistance in vector mosquitoes, as well as ecological, socio-economic 
and medical-sanitary factors [3,4]. Mosquito resistance to at least one insecticide used for malaria control has been identified in 64 countries [5]. Malaria vectors are part of the Anopheles genus, including nearly 484 species, distributed in seven subgenera [6], 70 of which showing vectorial competence for human malaria [7], with 41 of them being considered as dominant vector species [8] (Table 1).

\section{Use of insecticides against malaria vectors}

The strategic tools to fight malaria are oriented towards two principal directions: (i) prevention, by means of controlling vector mosquitoes; and (ii) case management, through malaria diagnosis and treatment with effective medicines, being the former considered as the most effective [12]. The techniques for controlling vector mosquitoes are didactically classified as: mechanical (elimination of breeding sites), biological (use of predators or parasitoids) or chemical (application of synthetic insecticides) [13,14]. The development of chemical insecticides that remain active for long periods of time was one of the most relevant breakthroughs of the 20th century [15] and nowadays they still play an important role in the control of disease vectors and plagues in agriculture.

There are four main groups of neurotoxic insecticides permitted to be used for public health purposes, classified according to their chemical nature and mode of action: organochlorines, organophosphates, carbamates and pyrethroids. The first insecticide used against anophelines was the DDT, an organochlorine firstly used in Naples in 1944 against a typhus epidemic [15]. In 1995, WHO proposed the global eradication of malaria based on the spraying of DDT inside the houses. Highly efficient and inexpensive, it was able to decimate populations of vectors on a global scale. However, the development of environmental and sanitary problems, coupled with the emergence of resistance, resulted in the prohibition of the product in many countries [16]. In spite of that, after the "Stockholm Convention on Persistent Organic Pollutants" in 2007, DDT was reestablished in restricted areas with high malaria transmission, such as in African locations [17].

The organophosphates (malathion, temephos, fenitrothion etc.) were developed in the 1940s and have been used ever since as insecticides, herbicides and plant growth regulators. Despite being biodegradable and non-cumulative, they have disadvantages, like chemical instability and high toxicity for vertebrates [18]. The carbamates, also referred to as methylcarbamates for deriving from the methylcarbamic acid [19], are compounds used as insecticides, nematicides and acaricides. They have low environmental persistence and are less toxic to living organisms than organochlorines. Due to their wide use in agriculture, they were incriminated as food, water and air contaminant agents, with adverse effects in humans and other animals [20]. Around 1970, synthetic pyrethroids were released as a class of insecticides considered more efficient and less toxic. These insecticides raised the attention for presenting higher lethal capacity against insects, requiring only small doses of the product for satisfactory effects [21]. Consequently, pyrethroids virtually substituted/supplemented the use of other classes in many pest control areas, representing nearly $23 \%$ of the chemical insecticides market, more than one fourth of the world market [22].

Pyrethroids are synthetic analogues of the chrysanthemic acid (pyrethrins I) and pyrethric acid (pyrethrins II) ester insecticides, naturally found in leaves of Chrysanthemum cinerafolis. They are chemically distinguished as type I, compounds that lack an alpha-cyano group, like permethrin, and type 2, with an alpha-cyano group, like deltamethrin [23]. They are biodegradable, non-cumulative insecticides that rarely cause acute intoxication in birds and mammals [24]. Currently, malaria control basically depends upon this insecticide class, which has been widely employed in indoor residual spraying (IRS) and also to control agricultural pests worldwide. Besides, pyrethroid is the only class approved by the World Health Organization Pesticide Scheme (WHOPES) for mosquito net impregnation (Insecticide Treated Net - ITN; Long Lasting Insecticide Treated Net - LLIN) $[1,25,26]$.

IRS is a method in which residual insecticides are applied on the surface of walls and ceilings of houses [27]. Based on this strategy it is expected that the mosquitoes, after feeding on blood, rest on these surfaces and remain long enough to absorb a lethal dose of the insecticide. ITN is a mosquito net that repels, incapacitates or kills mosquitoes that come into contact with the insecticide impregnated in the net material, being both a chemical and a physical barrier against insects.

Table 1 List of $\mathbf{4 1}$ dominant vector species by area

Continent Anopheline species

Africa Anopheles arabiensis, Anopheles funestus, Anopheles gambiae, Anopheles melas, Anopheles merus, Anopheles moucheti e Anopheles nili

Asia Anopheles barbirostris, Anopheles lesteri, Anopheles sinensis, Anopheles aconitus, Anopheles annularis, Anopheles balabacensis, Anopheles culicifacies, Anopheles dirus, Anopheles farauti, Anopheles flavirostris, Anopheles fluviatilis, Anopheles koliensis, Anopheles leucosphyrus, Anopheles maculatus, Anopheles minimus, Anopheles punctulatus, Anopheles stephensi, Anopheles subpictus e Anopheles sundaicus

Americas Anopheles freeborni, Anopheles pseudopunctipennis, Anopheles quadrimaculatus, Anopheles albimanus, Anopheles albitarsis, Anopheles aquasalis, Anopheles darlingi, Anopheles marajoara e Anopheles nuneztovari 
There are two ITN categories: conventional nets and LLIN $[27,28]$.

The initial success of insecticide based strategies caused the optimistic sensation that the elimination of malaria as a public health concern would be possible through the elimination of its vectors. However, these strategies are threatened today, due to the emergence of vector populations resistant to insecticides. Since new classes of alternative, equally interesting insecticides are not yet available on the market, the selection for resistance tends to continue increasing, unless effective management strategies are implemented [29].

\section{Review}

\section{Mode of action of pyrethroids}

Pyrethroids, such as DDT and its analogues, belong to a group of neurotoxins that share a similar mode of action. They all target $\mathrm{Na}_{v}$, which is present in cells of the central and peripheral nervous systems (neurons, myocytes, endocrine cells and ovaries), changing the kinetics of propagation of nerve impulses [22]. Structurally, $\mathrm{Na}_{\mathrm{V}}$ is an integral transmembrane protein, composed of four homologous domains (I-IV), each of them composed of six helices (S1-S6) connected by loops. The segments S5, S6 and the S5-S6 P-loops form a central aqueous pore, and the S1-S4 helices of each domain unite to form four independent voltage-sensitive domains [30,31]. The A. gambiae $\mathrm{Na}_{V}$ alpha subunit gene comprises an ORF (Open Reading Frame) with 6,417 nucleotides that encodes 2,139 amino acids, resulting in a protein with a molecular mass of $240 \mathrm{kDa}$. This gene, located at the para (paralysis) loco of the X chromosome, is composed of 35 exons, including two duplicated exons, and 32 introns, which transcribes for different messenger RNAs (mRNA) through alternate splicing [31].

The effects of pyrethroids are stereospecific and two different $\mathrm{Na}_{\mathrm{V}}$ binding sites were identified. The first was proposed by O'Reilly et al. [32], in which IIS5 and IIIS6 helices would play an important role in the interaction with the insecticide molecule and the additional link in the IIS4-S5 linker would explain the higher potency of pyrethroids compared with DDT. The second was suggested by Du et al. [33], where the binding site would be a type of "pocket" formed by the IS4-S5 linker and the helices IS5 and IIS6. For both models, the selective effect of the insecticide would be explained by the nonconservation of the amino acids of these regions between arthropods and other animals.

\section{Pyrethroid resistance mechanisms}

Insecticide resistance can be defined as the ability of individuals of a species to withstand doses of toxic substances, that would be lethal for most individuals of a population [34]. It is, therefore, a milestone in the change of the genetic composition of a given population, in response to the selection pressure. This is a typical case of Natural Selection, which consists in the increase of the relative frequencies of some "pre-adapted" individuals present in a population, resulting from the constant application of the same chemical product [35]. Intensive and extensive use of chemical insecticides has selected populations resistant to these compounds [36]. The resistance phenomenon has been observed in more than 500 insect species around the world, among which more than 50 are anophelines [37]. According to $\mathrm{WHO}$ [5], resistance to at least one insecticide had been identified in 64 malaria-endemic countries. Resistance to pyrethroids seems to be the most widespread. Two main mechanisms are incriminated as responsible for the pyrethroid resistance: metabolic resistance and targetsite insensitivity $[38,39]$.

Metabolic resistance occurs when high activity of one or more enzymes results in a sufficient portion of insecticide being sequestered or detoxified before reaching its target and promoting the desired effect [38]. It occurs due to the increase in the number of available molecules (genetic amplification or hyperactivation of the gene expression) or through mutations in the coding gene portion of the enzyme, producing the more efficient metabolization of the insecticide $[37,40,41]$. This mechanism is highly complex, although recent advances have been characterizing the main enzyme genes responsible for the detoxification, paving the way for the development of molecular markers for the resistance [42]. Three main enzyme superfamilies are involved in the detoxification process: Esterases, Mixed Function Oxidases (MFO, or simply P450) and Glutathione S-Transferases (GST) [37]. Colorimetric biochemical trials are widely employed to detect changes in the activity of detoxification enzymes. In this test, the enzymatic activity of a natural population is compared with the control lineages ones, using specific substrates for each enzymatic family [43].

On a transcriptional level, more recently microarray assays have gained prominence in the investigation of metabolic resistance. In this technique, the detoxification chips (or detox chips) compare the expression of virtually all genes of the families related to the metabolism of insecticides (GSTs, MFOs, Esterases), between resistant and susceptible mosquitoes. In addition to these main families, the expression of other genes are evaluated, such as some related to redox metabolism, involved in the protection against free radicals [44]. The analysis of the gene expression through detox chip in A. gambiae showed high activity of GST genes (GSTE2), P450 (CYP6Z1 and CYP325) and peroxidases in DDT resistant mosquitoes [44]. Genes with anti-oxidizing function (Superoxide dismutase, GST, Peroxidase and P450) were differently expressed in deltamethrinresistant populations of $A$. arabiensis in Cameroon [45]. High expression of CYP6P3, a gene of the P450 
family, was observed in permethrin-resistant populations of A. gambiae [46]. Differential expression was also observed in $A$. funestus, whose $\mathrm{P} 450$ genes (CYP6P9, CYP6M7) and COI (from the redox system) were more expressive in resistant individuals [47].

Resistance based on target-site insensitivity occurs when there is an alteration in the molecules that directly interact with the insecticide, making it less toxic or inefficient $[42,43,48]$. Since insecticide targets are structural molecules of the nervous system, highly conserved throughout evolution, few alterations are permissive without the loss of their physiological functions. Thus, it is common that the mutations selected for resistance occur at homologous sites among different insect species [49]. Target-site insensitivity is the most understood mechanism, and in many cases is the characteristic attributed to the higher portion of the genetic variation related to resistance [50]. In this sense, molecular diagnoses for detection target-site mutations are part of the strategies to monitor insecticide resistance in many malaria control programs [51].

\section{$K d r$ mutations as a resistance mechanism}

Many studies showed that resistance to the knockdown effect of several insect species is associated with point mutations in the $N a_{V}$ gene. By definition, the knockdown effect is the loss of coordination and paralysis caused by the insecticide, which are often accompanied by spasms and tremors [22]. This resistance mechanism was first observed in the housefly Musca domestica [52], where later it was suggested that the substitution of one amino acid leucine by phenylalanine in the hydrophobic segment IIS6 (L1014F) resulted in a moderate increase of DDT resistance, termed as the $k d r$ mutation (knockdown resistance). In Anopheles the homologous L1014F $k d r$ mutation was first identified in lineages of $A$. gambiae resistant to pyrethroids [53] and since then it has also been detected in a series of other anophelines [54-59]. Still in the 1014 site, another substitution, leucine by serine (L1014S), was identified in A. gambiae, also associated with the $k d r$ phenotype [60]. The mutations L1014F and L1014S were first observed in populations of West and East Africa, respectively. Therefore, the former is sometimes referred to as $k d r-w$ ( $k d r$-west), and the latter, as $k d r-e$ ( $k d r$-east) [61]. In any case, it is noticeable that the distribution of these mutations is strongly related to sibling species of the Anopheles gambiae complex [62].

In Asian A. sinensis populations, in addition to the L1014F/S substitutions, the mutations L1014C and L1014W were reported, changing the amino acid leucine to cysteine and to tryptophan, respectively. Additionally, in the site immediately before the one of the classical $k d r$ mutation, an N1013S substitution occurs, changing the amino acid asparagine to serine $[63,64]$. In Indian $A$. culicifacies populations, also in addition to the L1014F/S substitutions, a new mutation in the site 1010 was described, substituting valine by leucine (V1010L) [65].

Another mutation in the $\mathrm{Na}_{\mathrm{V}}$ of Musca domestica, which substitutes methionine by threonine in 918 position, corresponding to the loop between IIS4-S5 segments, synergic to the classical L1014F mutation, was associated with high levels of DDT and pyrethroid resistance, thus being referred to as super $k d r$ [66]. An analogous situation was observed in other insect species, such as in the horn fly Haematobia irritans [67], green peach aphid Myzus persicae [68,69], onion thrips Thrips tabaci [70] and in the moth Tuta absoluta [71]. However, there are still no records of homologous substitutions in anophelines.

Based on the current molecular techniques, it was possible to identify and map the distribution of $k d r$ mutations among a wide range of Anopheles species around the world. Since it was first described in 1998 [53], the identification of changes in the $N a_{V}$ gene in the Anopheles genus has been widely monitored, in a way that we were able to recorded about 98 references published until the end of 2013 (Table 2).

So far, $N a_{V}$ mutations were described in at least 13 different anophelines. A. gambiae was the most studied (62 records), showing three mutational variants (L1014F, L1014S and N1575Y), detected in 19 out of 54 countries in Africa (Figure 1). Following, the African A. arabiensis presented 17 records, showing two variants (L1014F and L1014S) detected in seven countries. A. sinensis was the third one, with six records. Surprisingly, it showed the highest number of $k d r$ variants (L1014F, L1014S, L1014C, L1014W and N1013S), distributed in five Asian countries, mostly detected in China. According to Kang et al. [142], this fact is related to the high population size and to the wide geographical distribution of the species, which tends to increase the genetic variability.

Among other Asian species, A. stephensi showed three records of two variants (L1014F and L1014S), detected in Dubai and India. A.subpictus (L1014F), A. culicifacies (L1014F, L1014S and V1010L) and $A$. vagus (L1014F) showed two records; while $A$. sacharovi (L1014F/L1014S), A. sundaicus (L1014F), A. aconitus (L1014F), A. paraliae (L1014S) and $A$. peditaeniatus (L1014F/L1014S) had just one record. The presence of $k d r$ mutations in the Americas was observed only in A. albimanus, for the variants L1014F and L1014C in populations from Mexico, Nicaragua and Costa Rica (Table 2).

A survey on the geographical distribution of $k d r$ mutations in African populations of A. gambiae, conducted by Pinto et al. [61], detected the presence of the variant L1014F in west countries $(k d r-w)$, from Nigeria to Senegal, the presence of L1014S ( $k d r-e)$ in the East (Kenya), and both mutations occurring in the Midwest, comprising 
Table 2 Anopheline species with $k d r$ mutations detected

\begin{tabular}{|c|c|c|c|}
\hline Species & Locality & Type of mutation & References \\
\hline \multicolumn{4}{|c|}{ Anopheles gambiae } \\
\hline & Ghana & L1014F/N1575Y/L1014S & {$[62,72-77]$} \\
\hline & Nigeria & L1014F/L1014S & {$[56,62,78-80]$} \\
\hline & Burkina Faso & L1014F/N1575Y/L1014S & {$[53,57,62,72,77,81-87]$} \\
\hline & Cameroon & L1014F/N1575/L1014S & {$[54,62,77,88-96]$} \\
\hline & Ivory Coast & L1014F/L1014S & {$[53,55,62,83,97-99]$} \\
\hline & Kenya & L1014S & {$[60,100-106]$} \\
\hline & Angola & L1014F/L1014S & {$[62,107]$} \\
\hline & Benin & L1014F/N1575Y/L1014S & {$[62,77,108-113]$} \\
\hline & Mali & L1014F/L1014S & {$[114,115]$} \\
\hline & Chad & L1014F & [116] \\
\hline & Congo & L1014F/L1014S & {$[117,118]$} \\
\hline & Equatorial Guinea & L1014F/L1014S & {$[54,119]$} \\
\hline & Gabon & L1014F/L1014S & {$[62,120,121]$} \\
\hline & Senegal & L1014F/L1014S & {$[62,122]$} \\
\hline & Uganda & L1014F/L1014S & [123-126] \\
\hline & Tanzania & L1014S & {$[127]$} \\
\hline & Burundi & L1014S & [128] \\
\hline & Liberia & L1014F & [129] \\
\hline & Niger & L1014F & [130] \\
\hline \multicolumn{4}{|c|}{ Anopheles arabiensis } \\
\hline & Sudan & L1014F/L1014S & [131-134] \\
\hline & Burkina Faso & L1014F/L1014S & {$[57,82,84,86,135,136]$} \\
\hline & Ethiopia & L1014F & {$[58,137]$} \\
\hline & Kenya & L1014S & {$[102,104]$} \\
\hline & Benin & L1014S & [112] \\
\hline & Tanzania & L1014F & [138] \\
\hline & Uganda & L1014S & [125] \\
\hline \multicolumn{4}{|c|}{ Anopheles sinensis } \\
\hline & China & L1014F/L1014S/L1014C/L1014W/N1013S & {$[64,139-141]$} \\
\hline & Korea & L1014F/L1014C & [142] \\
\hline & Laos & L1014S & [143] \\
\hline & Cambodia & L1014S & [143] \\
\hline & Vietnam & L1014S & [143] \\
\hline \multicolumn{4}{|c|}{ Anopheles stephensi } \\
\hline & Dubai & L1014F & {$[144]$} \\
\hline & India & L1014F/L1014S & {$[145,146]$} \\
\hline \multicolumn{4}{|c|}{ Anopheles subpictus } \\
\hline & Sri Lanka & L1014F & [147] \\
\hline & Indonesia & L1014F & [148] \\
\hline \multicolumn{4}{|c|}{ Anopheles albimanus } \\
\hline & Mexico & L1014F & [149] \\
\hline & Nicaragua & L1014C & [149] \\
\hline & Costa Rica & L1014C & [149] \\
\hline
\end{tabular}


Table 2 Anopheline species with $\boldsymbol{k d r}$ mutations detected (Continued)

\begin{tabular}{|c|c|c|c|}
\hline \multicolumn{4}{|l|}{ Anopheles sacharovi } \\
\hline & Turkey & L1014F/L1014S & {$[150]$} \\
\hline \multicolumn{4}{|l|}{ Anopheles culicifacies } \\
\hline & India & L1014F/L1014S/N1010L & {$[65,151]$} \\
\hline \multicolumn{4}{|l|}{ Anopheles sundaicus } \\
\hline & Indonesia & L1014F & [148] \\
\hline \multicolumn{4}{|l|}{ Anopheles aconitus } \\
\hline & Indonésia & L1014F & [148] \\
\hline \multicolumn{4}{|l|}{ Anopheles vagus } \\
\hline & Indonesia & L1014F & [148] \\
\hline & Laos & L1014S & [143] \\
\hline & Cambodia & L1014S & [143] \\
\hline & Vietnam & L1014S & [143] \\
\hline \multicolumn{4}{|l|}{ Anopheles paraliae } \\
\hline & Laos & L1014S & [143] \\
\hline & Cambodia & L1014S & [143] \\
\hline & Vietnam & L1014S & [143] \\
\hline \multicolumn{4}{|c|}{ Anopheles peditaeniatus } \\
\hline & Laos & L1014F/L1014S & [143] \\
\hline & Cambodia & L1014F/L1014S & [143] \\
\hline & Vietnam & L1014F/L1014S & [143] \\
\hline
\end{tabular}

Angola, Gabon, Equatorial Guinea and Cameroon. This same distribution pattern was reported one year later by Santolamazza et al. [62]. The occurrence of both mutations is currently found, sympatrically, in several African countries. Exceptions were Niger, Ethiopia, Chad and Liberia, which reported the presence of L1014F only, and Burundi and Kenya with L1014S only (Figure 1).

It is noteworthy that the A. gambiae complex is composed of seven sibling species: A. gambiae s.s., A arabiensis, A. melas, A. merus, Anopheles quadriannulatus species A, A. quadriannulatus species B and Anopheles bwambae. They are morphologically indistinguishable, however, they can be classified according to fixed and polymorphic chromosomal inversions [152]. The classical molecular forms are Savannah, Mopti, Bamako, Forest and Bissau, according to paracentric inversions of the second chromosome of $A$. gambiae s.s. [153]. The mutation L1014F was firstly described in the Savannah form of A. gambiae populations, also known as $\mathrm{S}$ form, and until mid-1999 this mutation had not occurred in sympatry with the Mopti form ( $\mathrm{M}$ form) [154]. However, later studies identified its presence also in the $\mathrm{M}$ form, possibly resulting from genetic introgression from the $\mathrm{S}$ form $[81,155]$. Introgression was also suggested by Tripet et al. [114] when the $k d r$ allele was detected in the Bamako form. On the other hand, a new independent mutational event could explain the emergence of the $k d r$ mutation in $A$. arabiensis [135].
Despite 15 years of research, some doubts still arise with respect to the $k d r$ mutations, especially if they are indeed correlated with the resistant phenotype. One of the techniques adopted to test this association is the employment of bioassays with insecticides (WHO cones, bottle test, ITN, LLIN) followed by the genotyping of $k d r$ mutation between dead and surviving mosquitoes after the test. In other words, it is aimed to test whether the mutation frequency is higher among resistant than the susceptible individuals. In our survey, out of the 98 studies here considered, 63 (64.3\%), conducted bioassay followed by genotyping, correlating the mutation with insecticide resistance. Among them six detected the involvement of more than one mechanism of resistance (target site and metabolic alterations) $[78,82,88,100,139,140]$ and two only suggested their occurrence $[123,129]$. On the other hand, six studies (9.5\%) did not associate the occurrence of $\mathrm{Na}_{\mathrm{V}}$ mutations with knockdown resistance $[58,107,119,131,136,143]$. In these cases, the lack of a "mutation versus resistance" association was suggested due to low sample size [107], mutation similarly distributed between dead and surviving individuals in the insecticide bioassay $[58,131,136,143]$ or mutation among susceptible individuals [119]. Nevertheless, in this last example the authors recognized that the bioassays were performed outside the WHO recommended standards. Lastly, in 28 studies (28.6\%) only the genotyping of field 


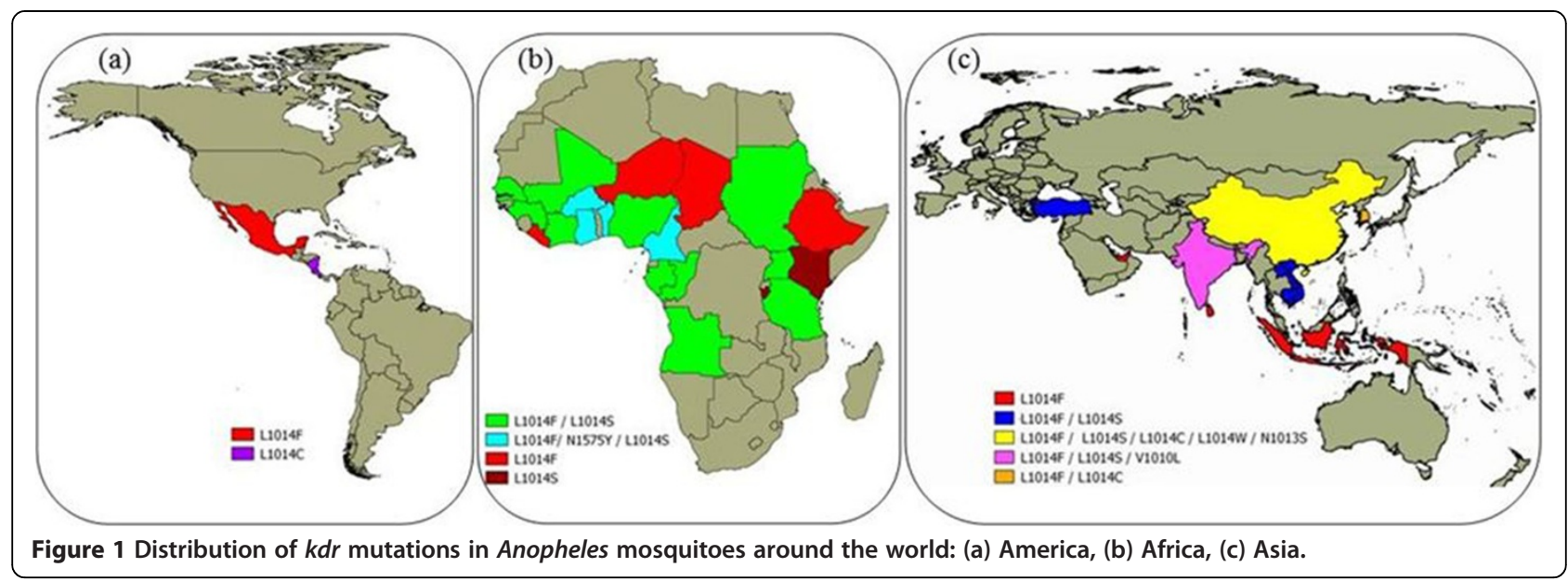

samples was performed, considering the presence of the mutation as enough evidence for resistance.

\section{Association between ITN and $k d r$ mutation}

The use of ITNs/LLINs treated with pyrethroids is an important tool to reduce morbidity and mortality caused by malaria [26]. According to a survey performed by Lengeler et al. [156], the implementation of this strategy in Sub-Saharan Africa, between 1986 and 2003, was able to reduce morbidity by $50 \%$ and the infant mortality by $17 \%$. In Kenya, for instance, the employment of ITNs was able to prevent infant mortality in an area with high malaria transmission [25]. However, the maintenance of this efficiency is still a controversial issue nowadays, given the occurrence of highly resistant anopheline populations. There are several records indicating good results of pyrethroid treated materials where $k d r$ mutation had been identified, such as in Nigeria [157], where the LLINs were efficient at killing or reducing the blood feeding of $A$. gambiae, Mali [115], Benin [108,158] and Uganda [124]. On the other hand, a reduction in the susceptibility of $A$. gambiae populations subjected to ITNs was observed in Uganda [159]. Besides that, increases in $k d r$ frequency were evidenced for this same species after the distribution of LLINs in Kenya [101], Niger [130], Senegal [122] and Benin [160].

The most recent update of WHOPES continues indicating only pyrethroids (deltamethrin, alphacypermethrin, permethrin and a combination of deltamethrin or permethrin and piperonyl butoxide - PBO) for LLINs [161]. However, given the possibility of loss of effectiveness caused by resistance, the development of mosquito nets impregnated with other classes of insecticides is a promising alternative. A study conducted with mosquito nets impregnated with chlorpyrifos-methyl (organophosphate) and lambdacyalothrin (pyrethroid), showed that, alone or combined, they were efficient at killing or reducing blood feeding of $A$. gambiae from the Ivory Coast, even in areas with high $k d r$ and $a c e-I^{R}$ mutation frequencies. This ace- $1^{R}$ mutant allele belongs to the acetylcholinesterase gene, conferring resistance to organophosphates [162].

\section{Association between Plasmodium infection and insecticide resistance}

Regardless of the extensive literature concerning $k d r$ mutations and their association with resistance to insecticides, few reports have presented their impact on malaria transmission dynamics, i.e., on the ability of mosquitoes to transmit malaria. Infection rate and oocyst burden are two of the five factors that determine the vectorial capacity of mosquitoes [163]. The response to Plasmodium exposure in vectors is modulated by the mosquito's innate immune system. In A. gambiae, for example, changes in its global gene expression patterns are expressed upon Plasmodium infection [164]. Exposure to pyrethroids, in turn, induces metabolic changes that alters the immune response [165] and may therefore affect the outcome of Plasmodium infection.

An insecticide susceptible strain of $A$. funestus showed greater ability to become infected with Plasmodium berghei than its resistant counterpart [166]. In A. gambiae, infection with this same parasite increased the expression level of CYP6M2, a gene related with metabolic resistance [164]. In relation to the possible impacts of $k d r$ mutation on vector competence, few records are available and are sometimes conflicting. For instance, neither positive or negative correlation was found between the occurrence of $k d r$ and $a c e-1^{R}$ alleles with infection of Plasmodium falciparum in A. gambiae natural populations from Benin [109].

Other studies, however, showed that the presence of both resistant alleles could be associated with increased prevalence of Plasmodium infection in an A. gambiae resistant strain. Additionally, individuals carrying the $k d r$ mutation had increased prevalence of sporozoites, which is likely to 
Table 3 Molecular methods used for detecting kdr mutations

\begin{tabular}{|c|c|c|c|}
\hline Method & Equipment required & Mutation & References \\
\hline Allele-Specific Polymerase Chain Reaction (AS-PCR) & PCR thermocycler, electrophoresis and imaging equipments & L1014F/S/C & {$[53,60]$} \\
\hline Heated Oligonucleotide Ligation Assay (HOLA) & PCR thermocycler, ELISA plate reader & L1014F/S & [168] \\
\hline Sequence-Specific Oligonucleotide Probe - Enzyme-Linked ImmunoSorbent Assay (SSOP-ELISA) & PCR thermocycler, shaking incubator and ELISA plate reader & L1014F/S & [138] \\
\hline PCR Sequence Specific Oligonucleotide Probe Assay (PCR-Dot Blot) & PCR thermocycler, shaking incubator and nylon membrane & L1014F/S & [169] \\
\hline Fluorescence Resonance Energy Transfer (FRET)/Melt Curve Analysis (MCA) & Real-Time PCR thermocycler & L1014F/S & [125] \\
\hline PCR Elongation with Fluorescence & PCR thermocycler and electrophoresis equipments & L1014F/S & [170] \\
\hline High Resolution Melt (HRM) & Real-Time PCR thermocycler & L1014F/S & [171] \\
\hline Allele-Specific Loop-Mediated Isothermal Amplification (AS-LAMP) & Turbidimeter and water bath & L1014F & [172] \\
\hline Polymerase Chain Reaction-Restriction Fragment Length Polymorphism assay (PCR-RFLP) & PCR thermocycler & L1014F/C & [141] \\
\hline Primer Introduced Restriction Analysis-PCR assay (PIRA-PCR) & PCR thermocycler, electrophoresis and imaging equipments & L1014F/S & [173] \\
\hline Multiplex Primer Introduced Restriction Analysis-PCR assay (mPIRA-PCR) & PCR thermocycler and electrophoresis equipments & L1014F/S & [174] \\
\hline Amplification Refractory Mutation System (ARMS) & PCR thermocycler, electrophoresis and imaging equipments & L1014F & [151] \\
\hline
\end{tabular}


impact on parasite transmission [167]. Given the dissemination of $k d r$ mutation in natural populations, similar studies should be conducted in order to better understand the impact of insecticide resistance on vector competence.

\section{Molecular tools for KDR mutation diagnosis}

The resistance phenomenon can be studied on many levels, from biological assays in order to evaluate the susceptibility/resistance status to biochemical and molecular characterizations able to infer the mechanisms and effective genes selected for resistance. Currently, the development of tools for genetic screening of natural populations on a large scale, are aimed to predict the predisposition of those populations to develop insecticide resistance.

Thus, the identification of genetic markers associated with resistance were included in the priorities of the WHO Global Plan for Insecticide Resistance Management (GPIRM) [5]. In this sense, the identification of $k d r$ genetic markers truly associated with pyrethroid resistance, as well as the improvement of existent diagnostic assays are constantly in the course of studies in this field. DNA based genotyping techniques have as main advantages the high sensitivity and the capacity to distinguish between homo and heterozygous individuals [37]. The principal methods employed in the detection of $k d r$ mutations are listed in Table 3, with emphasis on the equipment required for each technique.

\section{Strategies for managing resistance}

The evolution of insecticide resistance has become a great threat to chemical products-based malaria control programs due to the strong selection pressure placed on resistance genes [5]. Therefore, strategies for managing resistance to minimize operational obstacles to the use of a given product have gained prominence on the world stage. The resistance management strategies are divided into three groups: management by moderation, management by saturation and management by multiple attack [175].

Management by moderation aims to reduce the selection pressure to conserve susceptible individuals of a given population, by the use of lower dosages of insecticides, higher treatment thresholds, chemicals with shorter residual activity and maintaining unsprayed areas as refuges for susceptible individuals [176]. Even though, peculiarities have to be considered. For instance, a study evaluating the effects of sublethal doses of permethrin in an A. stephensi strain showed that lower concentrations were more efficient in increasing the mortality rates [177]. Concerning refuges, it is important to maintain susceptible alleles in a population, mainly in the case of resistant alleles, which carry a fitness cost. However, resistant alleles can also invade untreated areas. This was the case observed in a survey conducted in populations of $A$. gambiae from Burundi, where high frequencies of $k d r$ allele were detected in unsprayed areas, due to migration [128].

Management by saturation involves methods that overcome resistance mechanisms present in the insect, by the use of high rates of insecticides, that should kill even resistant individuals, or by the use of chemical synergists [21]. For example, the evaluation of the dosage-dependent effect of permethrin-treated nets in experimental hut trials from Benin showed that nets treated with higher permethrin concentrations provided better blood feeding prevention against pyrethroid-resistant A. gambiae [158]. Similar efficiency against pyrethroid-resistant $A$. gambiae populations were observed in a net impregnated with deltamethrinpyperonil butoxide combination [157,178].

Finally, the management by multiple attacks involves either mixtures or rotations of insecticides to avoid resistance. This method is based on the concept that insects resistant to one insecticide will be killed by the other component of the mixture and that few insects will be resistant to the entire mixture [176]. A combination of IRS with chlorfenapyr and LLIN impregnated with deltamethrin, in an experimental hut trial from Benin, was effective to provide additional level of transmission control and personal protection against pyrethroid-resistant A. gambiae [108]. Similar results were obtained by the use of mosquito nets impregnated with chlorpyrifos-methyl and lambdacyalothrin against $A$. gambiae from Ivory Coast [162].

\section{Conclusions}

After 15 years of intense research, $k d r$ mutations were recorded in 13 anopheline species, in natural populations from three continents, revealing the preponderance of this phenomenon in the process of resistance to pyrethroid insecticides, either alone or combined with other mechanisms (e.g., metabolic resistance). These alterations emerged in different species as well as within populations of the same species, and are spreading quickly, given the strong selection pressure exerted by the pyrethroids. Although compounds with new modes of action, such as neonicotinoids and pyrroles, have been introduced in public health, they are still not indicated for IRS and ITN, for instance. The availability of a new generation of environmentally friendly compounds may take as long as the implementation of advanced strategies, likewise, the use of genetically modified mosquitoes. Therefore, the use of pyrethroids has to be severely monitored in order to try to maximize their effectiveness.

\footnotetext{
Abbreviations

Nav: Voltage-gated sodium channel; DDT: Dichlorodiphenyltrichloroethane; Kdr: Knockdown resistance; WHO: World Health Organization; IRS: Indoor residual spraying; WHOPES: World Health Organization pesticide scheme; ITN: Insecticide treated net; LLIN: Long lasting insecticide treated net; MFO: Mixed function oxidases; GST: Glutathione S-Transferases; PBO: Piperonil-butoxide.
} 


\section{Competing interests}

The authors declare that they have no competing interests.

\section{Authors' contributions}

Study design (APBS, JMMS and AJM), data compilation from literature (APBS and AJM), writing and revision (APBS, JMMS and AJM). All authors read and approved the final version of the manuscript.

\section{Acknowledgements}

We are grateful to Juracy de Freitas Maia and staff at the Malaria and Dengue Group of the INPA, for their technical help, to Carlos Eduardo Freitas Lemos, for drawing the maps, to CNPq/CT-AMAZÔNIA, GCBEV/CAPES, FAPEAM/Rede Malaria and CT-PETRO for the financial support.

\section{Author details}

'Laboratório de Malária e Dengue, Instituto Nacional de Pesquisas da Amazônia, Av. André Araújo, 2936, Petrópolis, CEP 69067-375 Manaus, Amazonas, Brazil. 'Laboratório de Fisiologia e Controle de Artrópodes Vetores, Instituto Oswaldo Cruz, FIOCRUZ, Rio de Janeiro, Brazil. ${ }^{3}$ Instituto Nacional de Ciência e Tecnologia em Entomologia Molecular, Rio de Janeiro, Brazil.

Received: 3 April 2014 Accepted: 1 September 2014 Published: 7 October 2014

\section{References}

1. WHO: The World Health Report; 2006 [http://www.who.int/whr/2006/en/]

2. WHO: Malaria; 2013 [http://www.who.int/malaria/publications/world_ malaria_report_2013/en/]

3. Tadei WP, Thatcher BD, Santos JMM, Scarpassa VM, Rodrigues IB, Rafael MS Ecologic observations on anopheline vectors of malaria in the Brazilian Amazon. Am J Trop Med H 1998, 59(2):325-335.

4. WHO: Malaria Report: Global Malaria Programme. Geneva: World Health Organization; 2011.

5. WHO: Global Plan for Insecticide Resistance Management in Malaria Vectors (GPIRM). Geneva: World Health Organization; 2012.

6. Harbach RE: The classification of genus Anopheles (Diptera: Culicidae): a working hypothesis of phylogenetic relationships. B Entomol Res 2004, 95:537-553.

7. Service MW, Townson H: The Anopheles Vector. In Essential Malariology. 4th edition. Edited by Gilles HM, Warrell DA. London: Arnold; 2002:59-84.

8. Sinka ME, Bangs MJ, Manguin S, Rubio-Palis Y, Chareonviryiyaphap T, Coetzee M, Mbogo CM, Hemingway J, Patil AP, Temperley WH, Gething PW, Kabaria CW, Burkot TR, Harbach RE, Hay SI: A global map of dominant malaria vectors. Parasit Vectors 2012, 5:69.

9. Sinka ME, Bangs MJ, Manguin S, Coetzee M, Mbogo CM, Hemingway J, Patil AP, Temperley WH, Gething PW, Kabaria CW, Okara RM, Boeckel TV, Godfray HCJ, Harbach RE, Hay SI: The dominant Anopheles vectors of human malaria in Africa, Europe and the Middle East: occurrence data, distribution maps and bionomic précis. Parasit Vectors 2010, 3:117.

10. Sinka ME, Bangs MJ, Manguin S, Chareonviriyaphap T, Patil AP, Temperley WH, Gething PW, Elyazar IRF, Kabaria CW, Harbach RE, Hay SI: The dominant Anopheles vectors of human malaria in the Asia-Pacific region: occurrence data, distribution maps and bionomic précis. Parasit Vectors 2011, 4:89.

11. Sinka ME, Rubio-Palis $Y$, Manguin S, Patil AP, Temperley WH, Gething PW, Boeckel TV, Kabaria CW, Harbach RE, Hay SI: The dominant Anopheles vectors of human malaria in the Americas: occurrence data, distribution maps and bionomic précis. Parasit Vectors 2010, 3:72.

12. WHO: Global Malaria Control and Elimination: Report of a Technical Review. Geneva: World Health Organization; 2009.

13. Consoli RAGB, Lourenço-de-Oliveira R: Principais Mosquitos de Importância Sanitária no Brasil. Rio de Janeiro: Fiocruz; 1994.

14. Rose Rl: Pesticides and public health: integrated methods of mosquito management. Emerg Infect Dis 2001, 7(1):17-23.

15. Mellanby K: The DDT Story. United Kingdom: British Crop Protection Council; 1992.

16. Govere JM, Durrheim DN, Kunene S: Malaria trends in South Africa and Swaziland and the introduction of synthetic pyrethroids to replace DDT for malaria control. S Afr J Sci 2002, 98(1-2):19-21.
17. WHO: The Use of DDT in Malaria Vector Control. Geneva: World Health Organization; 2007.

18. Morales-Rojas H, Moss RA: Phosphorolytic reactivity of o-lodosylcarboxylates and related nucleophiles. Chem Rev 2002, 102(7):2497-2522.

19. Fukuto TR: Mechanism of action of organophosphorus and carbamate insecticides. Environ Health Persp 1990, 87:245-254.

20. Gupta RC: Carbofuran toxicity. J Toxicol Environ Health 1994, 43(4):383-418

21. Omoto C: Modo de Ação dos Inseticidas e Resistência de Insetos a Inseticidas. In Bases e Técnicas de Manejo de Insetos. Edited by Guedes JC, Costa ID, Castiglioni E. Santa Maria: Universidade Federal de Santa Maria; 2000:248.

22. Schleier JJ III, Peterson RKD: Pyrethrins and Pyrethroid Insecticides. In Green Trends in Insect Control. Edited by López O, Fernández-Bolaños JG. Cambridge: Royal Society of Chemistry; 2011:94-131.

23. Davies TGE, Field LM, Usherwood PNR, Williamson MS: DDT, pyrethrins, pyrethroids and insect sodium channels. Life 2007, 59(3):151-162.

24. Palchick S: The Biology of Disease Vectors. Colorado: University Press of Colorado; 1996.

25. Phillips-Howard PA, Nahlen BL, Kolczack MS, Hlghtower AW, Kuile FO, Alaii JA, Gimnig JE, Arudo J, Vulule JM, Odhacha A, Kachur SP, Schoute E, Rosen DH, Sexton JD, Oloo AJ, Hawley WA: Efficacy of permethrintreated bed nets in the prevention of mortality in young children in an area of high perennial malaria transmission in western Kenya. Am J Trop Med H 2003, 68:23-29.

26. WHO: Insecticide-Treated Mosquito Nets: a WHO Position Statement. Geneva: World Health Organization; 2007.

27. WHO: Guidelines for Testing Mosquito Adulticides for Indoor Residual Spraying and Treatment of Mosquito Nets. Geneva: World Health Organization; 2006.

28. Hill J, Lines J, Rowland M: Insecticide-treated nets. Adv Parasit 2006, 61:77-128.

29. Jones CM, Haji KA, Khatib BO, Bagi J, Mcha J, Devine GJ, Daley M, Kabula B, Ali AS, Majambere S, Ranson H: The dynamics of pyrethroid resistance in Anopheles arabiensis from Zanzibar and an assessment of the underlying genetic basis. Parasit Vectors 2013, 6:343.

30. Catterall WA, Chandy KG, Clapham DE, Gutman GA, Hofmann F, Harmar AJ, Abernethy DR, Spedding M: International Union of Pharmacology: Approaches to the nomenclature of voltage-gated ion channels. Pharmac Rev 2003, 55(4):573-574.

31. Davies TGE, Field LM, Usherwood PN, Williamson MS: A comparative study of voltage-gated sodium channels in the Insecta: implications for pyrethroid resistance in Anopheline and other Neopteran species. Insect Mol Biol 2007, 16(3):361-375.

32. O'Reilly AO, Khambay BPS, Williamson MS, Field LA, Wallace BA, Davies TGE: Modelling insecticide-binding sites in the voltage-gated sodium channel. Biochem J 2006, 396:255-263.

33. Du Y, Nomura Y, Satar G, Hu Z, Nauen R, He SY, Zhorov BS, Dong K: Molecular evidence for dual pyrethroid-receptor sites on a mosquito sodium channel. PNAS 2013, 110(29):11785-11790.

34. Subramanyam BH, Hagstrum DW: Resistance Measure and Management. In Integrated Management of Insects in Stored Products. Edited by Subramanyam BH, Hagstrum DW. New York: Marcel Dekker Inc; 1996.

35. Crow JF: Genetics of insecticide resistance to chemicals. Annu Rev Entomol 1957, 2:227-246.

36. Dong K: Insect sodium channels and insecticide resistance. Depart Entomol 2007, 7:17-30

37. Hemingway J, Ranson $\mathrm{H}$ : Insecticide resistance in insect vectors of human disease. Annu Rev Entomol 2000, 45:371-391.

38. Ranson H, N'Guessan R, Lines J, Moiroux N, Nkuni Z, Corbel V: Pyrethroid resistance in African anopheline mosquitoes: what are the implications for malaria control? Trends Parasit 2011, 27(2):91-98.

39. Martins AJ, Valle D: The pyrethroid knockdown resistance. In: Insecticides Basic and Other Applications. Edited by Soloneski S, Rijeka LM: In Tech; 2012:17-38.

40. Hemingway J: The molecular basis of two contrasting metabolic mechanisms of insecticide resistance. Insect Biochem Molec Biol 2000, 30:1009-1015.

41. Karaağaç SU: Insecticide resistance. In: Insecticides - Advances in Integrated Pest Management. Edited by Perveen F: In Tech; 2012:469-478.

42. Hemingway J, Hawkes NJ, McCarroll L, Ranson H: The molecular basis of insecticide resistance in mosquitoes. Insect Biochem Molec Biol 2004, 34:653-665. 
43. Brogdon WG, MCAllister JC: Insecticide resistance and vector control. Emerg Infect Dis 1998, 4(4):605-613.

44. David JP, Strode C, Vontas J, Nikou D, Vaughan A, Pignatelli PM, Louis C, Hemingway J, Ranson H: The Anopheles gambiae detoxification chip: a highly specific microarray to study metabolic-based insecticide resistance in malaria vectors. PNAS 2005, 102(11):4080-4084.

45. Müller P, Chouaibou M, Pignatelli P, Etang J, Walker ED, Donelly MJ, Simard $\mathrm{F}$, Ranson $\mathrm{H}$ : Pyrethroid tolerance is associated with elevated expression of antioxidants and agricultural practice in Anopheles arabiensis from an area of cotton fields in Northern Cameroon. Molec Ecol 2008, 17:1145-1155

46. Müller P, Warr E, Stevenson BJ, Pignatelli PM, Morgan JC, Steven A, Yawson AE, Mitchell SN, Ranson H, Hemingway J, Paine MJ, Donnelly MJ: Field-caught permethrin-resistant Anopheles gambiae overexpress CYP6P3, a P450 that metabolises pyrethroids. PLoS Genet 2008, 4(11):e1000286.

47. Christian RN, Strode C, Ranson H, Coetzer N, Coetzee M, Koekemoer LL: Microarray analysis of a pyrethroid resistant African malaria vector, Anopheles funestus, from southern Africa. Pestic Biochem Phys 2011, 99:140-147.

48. Pittendrigh BR, Margam VM, Sun L, Huesing JE: Resistance in the Post-Genomics Age. In Insect Resistance Management: Biology, Economics and Prediction. Edited by Onstad DW. Illinois: Elsevier Ltd; 2008:305.

49. Ffrench-Constant RH, Pittendrigh B, Vaughan A, Anthony N: Why are there so few resistance-associated mutations in insecticide target genes? Philos T Roy Soc B 1998, 353(1376):1685-1693.

50. Wondji CS, Morgan J, Coetzee M, Hunt RH, Steen K, Black WC IV Hemingway J, Ranson H: Mapping a Quantitative Trait Locus (QTL) conferring pyrethroid resistance in the African malaria vector Anopheles funestus. BioMed Central 2007, 8:34-47.

51. Corbel V, N'Guessan R: Distribution, mechanisms, impact and management of insecticide resistance in malaria vectors: a pragmatic review. In: Anopheles mosquitoes - New insights into malaria vectors. Edited by Manguin S: In tech; 2013:579-633.

52. Williamson MS, Martinez-Torres D, Hick CA, Devonshire AL: Identification of mutations in the housefly para- type sodium channel gene associated with knockdown resistance $(k d r)$ to pyrethroids insecticides. Mol Gen Genet 1996, 252:51-60.

53. Martinez-Torres D, Chandre E, Williamson MS, Darriet F, Bergé JB, Devonshire AL, Guillet P, Pasteur N, Pauron D: Molecular characterization of pyrethroid knockdown resistance $(k d r)$ in the major malaria vector Anopheles gambiae s.s. Insect Molec Biol 1998, 7(2):179-184.

54. Reimer LJ, Tripet F, Slotman M, Spielman A, Fondjo E, Lanzaro GC: An unusual distribution of the $k d r$ gene among populations of Anopheles gambiae on the Island of Bioko, Equatorial Guinea. Insect Molec Biol 2005, 14(6):683-688.

55. Girod R, Orlandi-Pradines E, Rogier C, Pages F: Malaria transmission and insecticide resistance of Anopheles gambie (Diptera: Culicidae) in the French Military Camp of Port- Bouet, Abidjan (Côte d'Ivoire): implications for vector control. J Med Entomol 2006, 43(5):1082-1087.

56. Awolola TS, Oduola AO, Oyewole 1O, Obansa JB, Amajoh CN, Koekemoer LL, Coetzee M: Dynamics of knockdown pyrethroid insecticide resistance alleles in a field population of Anopheles gambiae s.s. in southwestern Nigeria. J Vector Borne Dis 2007, 44:181-188.

57. Dabiré KR, Diabaté A, Namountougou M, Toé KH, Ouari A, Kengne P, Bass C, Baldet T: Distribution of pyrethroid and DDT resistance and the L1014F kdr mutation in Anopheles gambiae s.l. from Burkina-Faso (West Africa). T Roy Soc Trop Med H 2009, 103(11):1113-1120.

58. Balkew M, Ibrahim M, Koekemoer LL, Brooke BD, Engers J, Aseffa A, Michael TG, Elhassen I: Insecticide resistance in Anopheles arabiensis (Diptera: Culicidae) from villages in central, northern and south west Ethiopia and detection of $k d r$ mutation. Parasit Vectors 2010, 3:40

59. Coetzee M, Koekemoer LL: Molecular systematics and insecticide resistance in the major African malaria vector Anopheles funestus. Annu Rev Entomol 2013, 58:393-412.

60. Ranson $\mathrm{H}$, Jensen B, Vulule JM, Wang X, Hemingway J, Collins FH: Identification of a point mutation in the voltage-gated sodium channel gene of Kenyan Anopheles gambiae associated with resistance to DDT and pyrethroids. Insect Molec Biol 2000, 9(5):491-497.

61. Pinto J, Lynd A, Vicente JL, Santolamazza F, Randle NP, Gentile G, Moreno M, Simard F, Charlwood JD, Rosário VE, Caccone A, Torre AD, Donnelly MJ:
Multiple origins of knockdown resistance mutations in the Afrotropical mosquito vector Anopheles gambiae. Plos ONE 2007, 2(11):e1243.

62. Santolamazza F, Calzetta M, Etang J, Barrese E, Dia I, Caccone A, Donnelly MJ, Petrarca V, Simard F, Pinto J, Torre AD: Distribution of knock-down resistance mutations in Anopheles gambiae molecular forms in west and west-central Africa. Malar J 2008, 7:74.

63. Kim H, Baek JH, Lee WJ, Lee SH: Frequency detection of pyrethroid resistance allele in Anopheles sinensis populations by real-time PCR amplification of specific allele (rtPASA). Pestic Biochem Phys 2007, 87(1):54-61.

64. Tan WL, Li CX, Wang ZM, Liu MD, Dong YD, Feng XY, Wu ZM, Guo XX, Xing D, Zhang YM, Wang ZC, Zhao TY: First detection of multiple knockdown resistance $(k d r)$-like mutations in voltage-gated sodium channel using three new genotyping methods in Anopheles sinensis from Guangxi Province, China. J Med Entomol 2012,

49:1012-1020.

65. Singh OP, Dykes CL, Das MK, Pradhan S, Bhatt RM, Agrawal OP, Adak T: Presence of two alternative $k d r$-like mutations, L1014F and L1014S, and a novel mutation, $\mathrm{V} 1010 \mathrm{~L}$, in the voltage gated $\mathrm{Na}+$ channel of Anopheles culicifacies from Orissa, India. Malar J 2010, 9:146.

66. Ingles PJ, Adams PM, Knipple DC, Soderlund DM: Characterization of voltage-sensitive sodium channel gene coding sequences from insecticide-susceptible and knockdown-resistant house fly strains. Insect Biochem Molec Biol 1996, 26:319-326.

67. Jamroz RC, Guerrero FD, Kammlah DM, Kunz SE: Role of the $k d r$ and super-kdr sodium channel mutations in pyrethroid resistance: correlation of allelic frequency to resistance level in wild and laboratory populations of horn flies (Haematobia irritans). Insect Biochem Molec Biol 1998, 28(12):1031-1037.

68. Anstead JA, Mallet J, Denholm I: Temporal and spatial incidence of alleles conferring knockdown resistance to pyrethroids in the peach-potato aphid, Myzus persicae (Hemiptera: Aphididae), and their association with other insecticide resistance mechanisms. B Entomol Res 2007, 97(3):243-252.

69. Eleftherianos I, Foster SP, Williamson MS, Denholm I: Characterization of the M918T sodium channel gene mutation associated with strong resistance to pyrethroid insecticides in the peach-potato aphid, Myzus persicae (Sulzer). B Entomol Res 2008, 98:183-191.

70. Toda S, Morishita M: Identification of three point mutations on the sodium channel gene in pyrethroid-resistant Thrips tabaci (Thysanoptera: Thripidae). J Econ Entomol 2009, 102:2296-2300.

71. Haddi K, Berger M, Bielza P, Cifuentes D, Field LM, Gorman K, Rapisarda C, Williamson MS, Bass C: Identification of mutations associated with pyrethroid resistance in the voltage-gated sodium channel of the tomato leaf miner (Tuta absoluta). Insect Biochem Molec Biol 2012, 42:506-513.

72. Yawson AE, McCall PJ, Wilson MD, Donnelly MJ: Species abundance and insecticide resistance of Anopheles gambiae in selected areas of Ghana and Burkina Faso. Med Vet Entomol 2004, 18:372-377.

73. Adasi K, Hemingway J: Susceptibility to three pyrethroids and detection of knockdown resistance mutation in Ghanaian Anopheles gambiae sensu strictu. J Vector Ecol 2008, 33(2):255-262.

74. Adeniran TT, Brown CA, Rogers W, Wilson MD, Appawu MA, Boakye DA: Susceptibility status of Anopheles gambiae sensu stricto (Diptera: Culicidae) to pyrethroid and carbamate insecticides in the Greater Accra region of Ghana, West Africa. Inter J Trop Insect Sci 2009, 29(3):124-129.

75. Boakye DA, Adasi K, Appawu M, Brown CA, Wilson MD: Pattern of household insecticide use and pyrethroid resistance in Anopheles gambiae sensu stricto (Diptera: Culicidae) within the Accra metropolis of Ghana. Afr Entomol 2009, 17(2):125-130.

76. Agyepong N, Mak-Mensah EE, Brown CA: Prevalence of Anopheles gambiae s.s. and their pyrethroid knock down resistance pattern in five selected communities in kumasi metropolis using polymerase chain reaction (PCR). Eur J Exper Biol 2012, 2(2):304-310.

77. Jones CM, Liyanapathirana M, Agossa FR, Weetman D, Ranson H, Donelly MJ, Wilding CS: Footprints of positive selection associated with a mutation (N1575Y) in the voltage-gated sodium channel of Anopheles gambiae. PNAS 2012, 109(17):6614-6619.

78. Awolola TS, Oduola AMJ, Strode C, Koekemoer LL, Brooke B, Ranson H: Evidence of multiple pyrethroid resistance mechanisms in the malaria vector Anopheles gambiae sensu stricto from Nigeria. T Roy Soc Trop Med H 2009, 103(11):1139-1145. 
79. Awolola TS, Brooke BD, Hunt RH, Coetzee M: Resistance of the malaria vector Anopheles gambiae s.s. to pyrethroid insecticides, in southwestern Nigeria. Ann Trop Med Parasit 2002, 96(8):849-852.

80. Oduola AO, Idowu ET, Oyebola MK, Adeogun AO, Olojede JB, Otubanjo OA, Awolola TS: Evidence of carbamate resistance in urban populations of Anopheles gambiae s.s. mosquitoes resistant to DDT and deltamethrin insecticides in Lagos, South-Western Nigeria. Parasit Vectors 2012, 5:116.

81. Diabate A, Baldet T, Chandre C, Dabiré KR, Kengne P, Guiguemde TR, Simard F, Guillet P, Hemingway J, Hougard JM: kdr mutation, a genetic marker to assess events of introgression between the molecular $\mathrm{M}$ and $\mathrm{S}$ forms of Anopheles gambiae (Diptera: Culicidae) in the Tropical Savannah Area of West Africa. J Med Entomol 2003, 40(2):195-198.

82. Namountougou M, Simard F, Baldet T, Diabaté A, Ouédraogo B, Martin T, Dabiré RK: Multiple insecticide resistance in Anopheles gambiae s.l. populations from Burkina Faso, West Africa. PLOS ONE 2012, 7(11):e48412

83. Chandre F, Darriet F, Duchon S, Finot L, Manguin S, Carnevale P, Guillet P: Modifications of pyrethroid effects associated with $k d r$ mutation in Anopheles gambiae. Med Vet Entomol 2000, 14:81-88.

84. Diabate A, Brengues C, Baldet T, Dabiré KR, Hougard JM, Akogbéto M, Kengne P, Simard F, Guillet P, Hemingway J, Chandre F: The spread of the Leu-Phe $k d r$ mutation through Anopheles gambiae complex in Burkina Faso: genetic introgression and de novo phenomena. Trop Med Inter Health 2004, 9(12):1267-1273.

85. Dabiré KR, Diabaté A, Djogbenou L, Ouari A, N'Guessan R, Ouédraogo JB, Hougard JM, Chandre F, Baldet T: Dynamics of multiple insecticide resistance in the malaria vector Anopheles gambiae in a rice growing area in South-Western Burkina Faso. Malar J 2008, 7:188.

86. Badolo A, Traore A, Jones CM, Sanou A, Flood L, Guelbeogo WM, Ranson $H$, Sagnon NF: Three years of insecticide resistance monitoring in Anopheles gambiae in Burkina Faso: resistance on the rise? Malar J 2012, 11:232.

87. Dabiré RK, Namountougou M, Sawadogo SP, Yaro LB, Toé HK, Ouari A Gouagna LC, Simard F, Chandre F, Baldet T, Bass C, Diabaté A: Population dynamics of Anopheles gambiae s.l. in Bobo-Dioulasso city: bionomics, infection rate and susceptibility to insecticides. Parasit Vectors 2012, 5:127.

88. Nwane P, Etang J, Chouaibou M, Toto JC, Koffi A, Mimpfoundi R, Simard F: Multiple insecticide resistance mechanisms in Anopheles gambiae s.l. populations from Cameroon, Central Africa. Parasit Vectors 2013, 6:41.

89. Etang J, Fondjo E, Chandre E, Morlais I, Brengues C, Nwane P, Chouaibou M, Ndjemai $\mathrm{H}$, Simard F: First report of knockdown mutations in the malaria vector Anopheles gambiae from Cameroon. Am J Trop Med H 2006, 74(5):795-797

90. Etang J, Fondjo E, Chandre F, Morlais I, Brengues C, Nwane P, Chouaibou M, Ndjemai $H$, Simard F: Short report: first report of knockdown mutations in the malaria vector Anopheles gambiae from Cameroon. Am J Trop Med H 2006, 74(5):795-797.

91. Reimer L, Fondjo E, Patchoké S, Diallo B, Lee Y, Ng A, Ndjemai HM, Atanga J, Traore SF, Lanzaro G, Cornel AJ: Relationship between $k d r$ mutation and resistance to pyrethroid and DDT insecticides in natural populations of Anopheles gambiae. J Med Entomol 2008, 45(2):260-266.

92. Nwane P, Etang J, Chouaibou M, Toto JC, Hinzoumbé CK, Mimpfoundi R, Ambene HPF, Simard F: Trends in DDT and pyrethroid resistance in Anopheles gambiae s.s. populations from urban and agro-industrial settings in southern Cameroon. BMC Infect Dis 2009, 9:163.

93. Bigoga JD, Ndangoh DN, Ambene PHA, Patchoké S, Fondjo E, Leke RGF: Pyrethroid resistance in Anopheles gambiae from the rubber cultivated area of Niete, South Region of Cameroon. Acta Trop 2012, 124:210-214.

94. Chouaibou M, Etang J, Brévault T, Nwane P, Hinzoumbé CK, Mimpfoundi R, Simard F: Dynamics of insecticide resistance in the malaria vector Anopheles gambiae s.l. from an area of extensive cotton cultivation in Northern Cameroon. Trop Med Inter Health 2008, 13(4):476-486.

95. Nwane P, Etang J, Chouaibou M, Toto JC, Mimpfoundi R, Simard F: kdr-based insecticide resistance in Anopheles gambiae s.s. populations in Cameroon: spread of the L1014F and L1014S mutations. BMC Res Notes 2011, 4:463.

96. Ndjemai HNM, Patchoké S, Atanga J, Etang J, Simard F, Bilong CFB, Reimer L, Cornel A, Lanzaro GC, Fondjo E: The distribution of insecticide resistance in Anopheles gambiae s.l. populations from Cameroon: an update. Trans Roy Soc Trop Med Hyg 2009, 103:1127-1138.

97. Edi CVA, Koudou BG, Jones CM, Weetman D, Ranson H: Multiple-insecticide resistance in Anopheles gambiae mosquitoes, Southern Côte d'Ivoire. Emerg Infect Dis 2012, 18(9):1508-1511.
98. Koffi AA, Alou LPA, Adja MA, Chandre F, Pennetier C: Insecticide resistance status of Anopheles gambiae s.s. population from M'Bé: a WHOPESlabelled experimental hut station, 10 years after the political crisis in Côte d'Ivoire. Malar J 2013, 12:151.

99. Koffi AA, Alou LPA, Kabran JP, N'Guessan R, Pennetier C: Re-visiting insecticide resistance status in Anopheles gambiae from Côte d'Ivoire: a nation-wide informative survey. PLOS ONE 2013, 8(12):e82387.

100. Ochomo E, Bayoh MN, Brogdon WG, Gimnig JE, Ouma C, Vulule JM, Walker ED: Pyrethroid resistance in Anopheles gambiae s.s. and Anopheles arabiensis in western Kenya: phenotypic, metabolic and target site characterizations of three populations. Medic Vet Entomol 2013, 27:156-164.

101. Stump AD, Atieli FK, Vulule JM, Besansky NJ: Dynamics of the pyrethroid knockdown resistance allele in western Kenyan populations of Anopheles gambiae in response to insecticide treated bed net trials. Am J Trop Med H 2004, 70(6):591-596

102. Chen H, Githeko AK, Githure Jl, Mutunga J, Zhou G, Yan G: Monooxygenase levels and knockdown resistance $(k d r)$ allele frequencies in Anopheles gambiae and Anopheles arabiensis in Kenya. J Med Entomol 2008, 45(2):242-250.

103. Kawada H, Dida GO, Ohashi K, Komagata O, Kasai S, Tomita T, Sonye G, Maekawa Y, Mwatele C, Njenga SM, Mwandawiro C, Minakawa N, Takagi M: Multimodal pyrethroid resistance in malaria vectors, Anopheles gambiae s.S., Anopheles arabiensis, and Anopheles funestus s.s. in western Kenya. PLOS ONE 2011, 6(8):e22574.

104. Kawada H, Futami K, Komagata O, Kasai S, Tomita T, Sonye G, Mwatele C, Njenga SM, Mwandawiro C, Minakawa N, Takagi M: Distribution of a knockdown resistance mutation (L1014S) in Anopheles gambiae s.s. and Anopheles arabiensis in Western and Southern Kenya. PLOS ONE 2011, 6(9):e24323.

105. Mathias DK, Ochomo E, Atieli F, Ombok M, Bayoh MN, Olang G, Muhia D, Kamau L, Vulule JM, Hamel MJ, Hawley WA, Walker ED, Gimnig JE: Spatial and temporal variation in the kdr allele L1014S in Anopheles gambiae s. s. and phenotypic variability in susceptibility to insecticides in Western Kenya. Malar J 2011, 10:10.

106. Ochomo EO, Bayoh NM, Walker ED, Abongo BO, Ombok MO, Ouma C, Githeko AK, Vulule J, Yan G, Gimnig JE: The efficacy of long-lasting nets with declining physical integrity may be compromised in areas with high levels of pyrethroid resistance. Malar J 2013, 12:368.

107. Cuamba N, Choi KS, Townson H: Malaria vectors in Angola: distribution of species and molecular forms of the Anopheles gambiae complex, their pyrethroid insecticide knockdown resistance $(k d r)$ status and Plasmodium falciparum sporozoite rates. Malar J 2006, 5:2

108. Ngufor C, N'Guessan R, Boko P, Odjo A, Vigninou E, Asidi A, Akogbéto M, Rowland $\mathrm{M}$ : Combining indoor residual spraying with chlorfenapyr and long-lasting insecticidal bed nets for improved control of pyrethroidresistant Anopheles gambiae: an experimental hut trial in Benin. Malar J 2011, 10:343.

109. Ossè $\mathrm{R}$, Gnanguenon V, Sèzonlin M, Aïkpon $\mathrm{R}$, Padonou $\mathrm{G}$, Yadouléton $\mathrm{A}$, Akogbéto MC: Relationship between the presence of $k d r$ and Ace-1 mutations and the infection with Plasmodium falciparum in Anopheles gambiae s.s. in Benin. J Parasit Vector Biol 2012, 4(3):31-39.

110. Yadouleton AWM, Asidi A, Djouaka RF, Braïma J, Agossou CD, Akogbéto MC: Development of vegetable farming: a cause of the emergence of insecticide resistance in populations of Anopheles gambiae in urban areas of Benin. Malar J 2009, 8:103.

111. Yadouleton AW, Padanou G, Asidi A, Moiroux N, Banganna SB, Corbel V, N'Guessan R, Gbenou D, Yacoubou I, Gazard K, Akogbéto MC: Insecticide resistance status in Anopheles gambiae in southern Benin. MalarJ 2010, 9:83.

112. Djégbe I, Boussari O, Sidick A, Martin T, Ranson H, Chandre F, Akogbéto M, Corbel $V$ : Dynamics of insecticide resistance in malaria vectors in Benin: first evidence of the presence of L1014S kdr mutation in Anopheles gambiae from West Africa. Malar J 2011, 10:261.

113. Padonou GG, Sezonlin M, Ossè R, Aïzoun N, Agbo FO, Oussou O, Gbédjissi G, Akogbéto M: Impact of three years of large scale indoor residual spraying (IRS) and insecticide treated nets (ITNs) interventions on insecticide resistance in Anopheles gambiae s.l. in Benin. Parasit Vectors 2012, 5:72.

114. Tripet F, Wright J, Cornel A, Fofana A, Mcabee R, Meneses C, Reimer L, Slotman M, Thiemann T, Dolo G, Traoré S, Lanzaro G: Longitudinal survey 
of knockdown resistance to pyrethroid ( $k d r$ ) in Mali, West Africa, and evidence of its emergence in the Bamako form of Anopheles gambiae s.s. Am J Trop Med H 2007, 76(1):81-87.

115. Fryxell RTT, Seifert SN, Lee Y, Sacko A, Lanzaro G, Cornel A: The knockdown resistance mutation and knockdown time in Anopheles gambiae collected from Mali evaluated through a bottle bioassay and a novel insecticide-treated net bioassay. J Am Mosquito Contr 2012, 28(2):119-122.

116. Hinzoumbé CK, Péka M, Nwane P, Gouni ID, Etang J, Ekobo AS, Simard F: Insecticide resistance in Anopheles gambiae from south-western Chad, Central Africa. Malar J 2008, 7:192.

117. Koekemoer LL, Spillings BL, Christian RN, Lo TCM, Kaiser ML, Norton RAl, Oliver SV, Choi KS, Brooke BD, Hunt RH, Coetzee M: Multiple insecticide resistance in Anopheles gambiae (Diptera: Culicidae) from Pointre Noire, Republic of the Congo. Vector-Borne Zoon Dis 2011, 11(8):1193-1200.

118. Kanza JPB, Fahime EE, Alaoui S, Essassi EM, Brooke B, Malafu AN, Tezzo FW: Pyrethroid, DDT and malathion resistance in the malaria vector Anopheles gambiae from the Democratic Republic of Congo. Trans Roy Soc Trop Med Hyg 2013, 107:8-14.

119. Moreno M, Vicente JL, Cano J, Bersoza PJ, Lucio A, Nzambo S, Bobuakasi L, Buatiche JN, Ondo M, Micha F, Rosario VE, Pinto J, Benito A: Knockdown resistance mutations ( $k d r)$ and insecticide susceptibility to DDT and pyrethroids in Anopheles gambiae from Equatorial Guinea. Trop Med Int Health 2008, 13(3):430-433.

120. Pinto J, Lynd A, Elissa N, Donnelly MJ, Costa C, Gentile C, Caccone A, Rosário VE: Co-occurrence of East and West African kdr mutations suggest high levels of resistance to pyrethroid insecticides in Anopheles gambiae from Libreville, Gabon. Med Vet Entomol 2006, 20:27-32.

121. Mourou JR, Coffinet T, Jarjaval F, Pradines B, Amalvict R, Rogier C, Kombila $M$, Pagès F: Malaria transmission and insecticide resistance of Anopheles gambiae in Libreville and Port-Gentil, Gabon. Malar J 2010, 9:321.

122. Ndiath MO, Sougoufara S, Gaye A, Mazenot C, Konate L, Faye O, Sokhna C, Trape JF: Resistance to DDT and pyrethroids and increased kdr mutation frequency in Anopheles gambiae after the implementation of permethrin-treated nets in Senegal. PLOS ONE 2012, 7(2):e31943.

123. Verhaeghen $K$, Bortel WW, Roelants $P$, Okello PE, Talisuna A, Coosemans M: Spatio-temporal patterns in $k d r$ frequency in permethrin and DDT resistant Anopheles gambiae s.s. from Uganda. Am J Trop Med H 2010, 82(4):566-573

124. Okia M, Ndyomugyenyi R, Kirunda J, Byaruhanga A, Adibaku S, Lwamafa DK, Kironde F: Bioefficacy of long-lasting insecticidal nets against pyrethroidresistant populations of Anopheles gambiae s.s. from different malaria transmission zones in Uganda. Parasit Vectors 2013, 6:130.

125. Verhaeghen K, Bortel W, Roelants P, Backeljau T, Coosemans M: Detection of the East and West African kdr mutation in Anopheles gambiae and Anopheles arabiensis from Uganda using a new assay based on FRET/ Melt Curve analysis. Malar J 2006, 5:16.

126. Ramphul U, Boase T, Bass C, Okedi LM, Donelly MJ, Müller P: Insecticide resistance and its association with target-site mutations in natural populations of Anopheles gambiae from eastern Uganda. Trans Roy Soc Trop Med Hyg 2009, 103:1121-1126.

127. Protopopoff N, Matowo J, Malima R, Kavishe R, Kaaya R, Wright A, West PA, Kleinschmidt I, Kisinza W, Mosha FW, Rowland M: High level of resistance in the mosquito Anopheles gambiae to pyrethroid insecticides and reduced susceptibility to bendiocarb in north-western Tanzania. Malar J 2013, 12:149.

128. Protopopoff N, Verhaeghen K, Bortel WV, Roelants P, Marcotty T, Baza D, D'Alessandro U, Coosemans M: A significant increase in $k d r$ in Anopheles gambiae is associated with an intensive vector control intervention in Burundi highlands. Trop Med Inter Health 2008, 13(12):1479-1487.

129. Temu EA, Maxwell C, Munyekenye G, Howard AFV, Munga S, Avicor SW, Poupardin R, Jones JJ, Allan R, Kleinschmidt I, Ranson H: Pyrethroid resistance in Anopheles gambiae, in Bomi County, Liberia, compromises malaria vector control. PLOS ONE 2012, 7(9):e44986.

130. Czeher C, Labbo R, Arzika I, Duchemin JB: Evidence of increasing Leu-Phe knockdown resistance mutation in Anopheles gambiae from Niger following a nationwide long-lasting insecticide-treated nets implementation. Malar J 2008, 7:189.

131. Matambo TS, Abdalla H, Brooke BD, Koekemoer LL, Mnzava A, Hunt RH, Coetzee M: Insecticide resistance in the malarial mosquito Anopheles arabiensis and association with the kdr mutation. Medic Vet Entomol 2007, 21:97-102.
132. Himeidan YE, Chen H, Chandre F, Donnelly MJ, Yan G: Permethrin and DDT resistance in the malaria vector Anopheles arabiensis from Eastern Sudan. Am J Trop Med H 2007, 77(6):1066-1068.

133. Himeidan YE, Hamid MMA, Jones CM, Ranson H: Extensive permethrin and DDT resistance in Anopheles arabiensis from eastern and central Sudan. Parasit Vectors 2011, 4:154

134. Abuelmaali SA, Elaagip AH, Basheer MA, Frah EA, Ahmed FTA, Elhaj HFA, Seidahmed OME, Weetman D, Hamid MMA: Impacts of agricultural practices on insecticide resistance in the malaria vector Anopheles arabiensis in Khartoum State, Sudan. PLoS ONE 2013, 8(11):e80549.

135. Diabate A, Baldet T, Chandre E, Dabiré KR, Simard F, Ouedraogo JB, Guillet $P$, Hougard JM: First report of a kdr mutation in Anopheles arabiensis from Burkina Faso, West Africa. J Am Mosquito Contr 2004, 20:195-196.

136. Jones CM, Toé HK, Sanou A, Namountougou M, Hughes A, Diabaté A, Dabiré R, Simard F, Ranson $\mathrm{H}$ : Additional selection for insecticide resistance in urban malaria vectors: DDT resistance in Anopheles arabiensis from Bobo-Dioulasso, Burkina Faso. PLoS ONE 2012, 7(9):e45995.

137. Yewhalaw D, Bortel WV, Denis L, Coosemans M, Duchateau L, Speybroeck N: First evidence of high knockdown resistance frequency in Anopheles arabiensis (Diptera: Culicidae) from Ethiopia. Am J Trop Med H 2010, 83 (1):122-125.

138. Kulkarni MA, Rowland M, Alifrangis M, Mosha FW, Matowo J, Malima R, Peter J, Kweka E, Lyimo I, Magesa S, Salanti A, Rau ME, Drakeley C: Occurrence of the leucine-to-phenylalanine knockdown resistance (kdr) mutation in Anopheles arabiensis populations in Tanzania, detected by a simplified high-throughput SSOP-ELISA method. MalarJ 2006, 5:56

139. Chang XL, Xue YQ, Zhang AD, Zhu GD, Fang Q: Deltamethrin resistance, metabolic detoxification enzyme and $k d r$ mutation in Anopheles sinensis in region along Huaihe River in Anhui Province. Zhongguo Xue Xi Chong Bing Fang Zhi Za Zhi 2013, 25(3):263-267.

140. Zhong D, Chang X, Zhou G, He Z, Fu F, Yan Z, Zhu G, Xu T, Bonizzoni M, Wang MH, Cui L, Zheng B, Chen B, Yan G: Relationship between knockdown resistance, metabolic detoxification and organismal resistance to pyrethroids in Anopheles sinensis. PLOS ONE 2013, 8(2):e55475.

141. Tan WL, Wang ZM, Li CX, Chu HL, Xu Y, Dong YD, Wang ZC, Chen DY, Liu H, Liu DP, Liu N, Sun J, Zhao T: First report on co-occurrence knockdown resistance mutations and susceptibility to beta-cypermethrin in Anopheles sinensis from Jiangsu Province. China. PLoS ONE 2012, 7(1):e29242.

142. Kang S, Jung J, Lee S, Hwang H, Kim W: The polymorphism and the geographical distribution of the knockdown resistance $(k d r)$ of Anopheles sinensis in the Republic of Korea. Malar J 2012, 11:151.

143. Verhaeghen K, van Bortel W, Trung HD, Sochantha T, Koeokenchanh K, Coosemans M: Knockdown resistance in Anopheles vagus, An. sinensis, An. paraliae and An. peditaeniatus populations of the Mekong region. Parasit Vectors 2010, 3:59

144. Enayati AA, Vatandoost $H$, Ladonni $H$, Townson $H$, Hemingway J: Molecular evidence for a kdr-like pyrethroid resistance mechanism in the malaria vector mosquito Anopheles stephensi. Med Vet Entomol 2003, 17:138-144.

145. Gayathri V, Murthy PB: Reduced susceptibility to deltamethrin and $k d r$ mutation in Anopheles stephensi Liston, a malaria vector in India. J Am Mosquito Contr 2006, 22(4):678-688.

146. Singh OP, Dykes CL, Lather M, Agrawal OP, Adak T: Knockdown resistance $(k d r)$-like mutations in the voltage-gated sodium channel of a malaria vector Anopheles stephensi and PCR assays for their detection. Malar J 2011, 10:59.

147. Karunaratne SH, Hawkes NJ, Perera MD, Ranson H, Hemingway J: Mutated sodium channel genes and elevated monooxygenases are found in pyrethroid resistant populations of Sri Lankan malaria vectors. Pestic Biochem Phys 2007, 88(1):108-113.

148. Syafruddin D, Hidayati APN, Asih PBS, Hawley WA, Sukowati S, Lobo NF: Detection of $1014 \mathrm{~F} k d r$ mutation in four major Anopheline malaria vectors in Indonesia. Malar J 2010, 9:315.

149. Lol JC, Castellanos ME, Liebman KA, Lenhart A, Pennington PM, Padilla NR: Molecular evidence for historical presence of knock-down resistance in Anopheles albimanus, a key malaria vector in Latin America. Parasit Vectors 2013, 6:268.

150. Lüleyap HP, Alptekin D, Kasap H, Kasap M: Detection of knockdown resistance mutations in Anopheles sacharovi (Diptera: Culicidae) and genetic distance with Anopheles gambiae (Diptera: Culicidae) using 
CDNA sequencing of the voltage-gated sodium channel gene. J Med Entomol 2002, 39(6):870-874.

151. Singh OP, Bali P, Hemingway J, Subbarao SK, Dash AP, Adak T: PCR-based methods for the detection of L1014 kdr mutation in Anopheles culicifacies sensu lato. Malar J 2009, 8:154.

152. Slotman MA, Della Torre A, Calzetta M, Powell JR: Differential introgression of chromosomal regions between Anopheles gambiae and An. arabiensis. Am J Trop Med H 2005, 73(2):326-335.

153. Coluzzi M, Sabatini A, Petrarca V, Di Deco MA: Chromosomal differentiation and adaptation to human environments in the Anopheles gambiae complex. T Roy Soc Trop Med H 1979, 73:483-497.

154. Chandre F, Brengues C, Dossou-Yovo J, Ma GS, Darriet F, Diabate A, Carnevale P, Guillet P: Current distribution of a pyrethroid resistance gene $(k d r)$ in Anopheles gambiae complex from West Africa and further evidence for reproductive isolation of the Mopti form. Parassitologia 1999, 41:319-322.

155. Weill M, Chandre F, Brengues C, Manguin S, Akogbéto M, Pasteur N, Guillet P, Raymond M: The kdr mutation occurs in the Mopti form of Anopheles gambiae s.s. through introgression. Insect Molec Biol 2000, 9(5):451-455.

156. Lengeler $C$ : Insecticide-treated bed nets and curtains for preventing malaria. Cochrane Db Syst Rev 2004, 2:CD000363.

157. Adeogun AO, Olojede JB, Oduola AO, Awolola TS: Village-scale evaluation of PermaNet 3.0: an enhanced efficacy combination long-lasting insecticidal net against resistant population of Anopheles gambiae s.s. Malaria Chem Contr Elim 2012, 1:1-9.

158. Corbel V, Chandre F, Brengues C, Akogbéto M, Lardeux F, Hougard JM, Guillet P: Dosage-dependent effects of permethrin-treated nets on the behaviour of Anopheles gambiae and the selection of pyrethroid resistance. Malar J 2004, 3:22.

159. John R, Ephraim T, Andrew A: Reduced susceptibility to pyrethroid insecticide treated nets by the malaria vector Anopheles gambiae s.l. in western Uganda. Malar J 2008, 7:92.

160. Aïzoun N, Aikpon R, Akogbéto M: Evidence of increasing L1014F kdr mutation frequency in Anopheles gambiae s.l. pyrethroid resistant following a nationwide distribution of LLINs by the Beninese National Malaria Control Programme. Asia Pac J Trop Biomed 2014, 4(3):239-243.

161. WHOPES: WHO recommended long-lasting insecticidal nets. [http://www.who. int/whopes/Long_lasting_insecticidal_nets_06_Feb_2014.pdf?ua=1]

162. Asidi AN, N'Guessan R, Koffi AA, Curtis CF, Hougard JM, Chandre F, Corbel V, Darriet F, Zaim M, Rowland MW: Experimental hut evaluation of bednets treated with an organophosphate (chlorpyrifos-methyl) or a pyrethroid (lambdacyhalothrin) alone and in combination against insecticideresistant Anopheles gambiae and Culex quinquefasciatus mosquitoes. Malar J 2005, 4:25.

163. Vézilier J, Nicot A, Gandon S, Rivero A: Insecticide resistance and malaria transmission: infection rate and oocyst burden in Culex pipiens mosquitoes infected with Plasmodium relictum. Malar J 2010, 9:379.

164. Félix RC, Müller P, Ribeiro V, Ranson H, Silveira H: Plasmodium infection alters Anopheles gambiae detoxification gene expression. BMC Gen 2010 11:312.

165. James RR, Xu J: Mechanisms by which pesticides affect insect immunity. $J$ Invert Pat 2012, 109(2):175-182.

166. Lo TM, Coetzee M: Marked biological differences between insecticide resistant and susceptible strains of Anopheles funestus infected with the murine parasite Plasmodium berghei. Parasit Vectors 2013, 6:184.

167. Alout H, Ndam NT, Sandeu MM, Djégbe I, Chandre F, Dabiré KR, Djogbénou $L S$, Corbel V, Cohuet A: Insecticide resistance alleles affect vector competence of Anopheles gambiae s.s. for Plasmodium falciparum field isolates. PLoS ONE 2013, 8(5):e63849.

168. Lynd A, Ranson H, McCall PJ, Randle NP, Black WC IV, Walker ED, Donnelly MJ: A simplified high-throughput method for pyrethroid knock-down resistance $(k d r)$ detection in Anopheles gambiae. Malar J 2005, 4:16.

169. Kolaczinski JH, Fanello C, Hervé JP, Conway DJ, Carnevale P, Curtis CF: Experimental and molecular genetic analysis of the impact of pyrethroid and non-pyrethroid insecticide impregnated bednets for mosquito control in an area of pyrethroid resistance. B Entomol Res 2000, 90(02):125-132.

170. Tripet F, Wright J, Lanzaro G: A new high-performance PCR diagnostic for the detection of pyrethroid knockdown resistance kdr in Anopheles gambiae. Am J Trop Med H 2006, 74(4):658-662.
171. Liew M, Pryor R, Palais R, Meadows C, Erali M, Lyon E, Wittwer C: Genotyping of single-nucleotide polymorphisms by High-Resolution Melting of small amplicons. Clinic Chem 2004, 50:1156-1164.

172. Badolo A, Okado K, Guelbeogo WM, Aonuma H, Bando H, Fukumoto S, Sagnon NF, Kanuka H: Development of an allele-specific, loop-mediated, isothermal amplification method (AS-LAMP) to detect the L1014F kdr-w mutation in Anopheles gambiae s.l. Malar J 2012, 11:227.

173. Janeira F, Vicente JL, Kanganje Y, Moreno M, Rosário VE, Cravo P, Pinto J: A primer-introduced restriction analysis-polymerase chain reaction method to detect knockdown resistance mutations in Anopheles gambiae. $J$ Med Entomol 2008, 45(2):237-241.

174. Kazanidou A, Nikou D, Grigoriou M, Vontas J, Skavdis G: A Multiplex PCR Assay for simultaneous genotyping of $k d r$ and ace- 1 loci in Anopheles gambiae. Am J Trop Med H 2009, 80(2):236-238.

175. Georghiou GP: Management of Resistance in Arthropods. In Pest Resistance to Pesticides. Edited by Georghiou GP, Saito T. New York: Plenum; 1983:769-792.

176. Dennehy TJ, Dunley J: Managing pesticide resistance. [http://jenny.tfrec.wsu. edu/opm/displayspecies.php?pn=-70]

177. Glunt KD, Thomas MB, Read AF: The effects of age, exposure history and malaria infection on the susceptibility of Anopheles mosquitoes to low concentrations of pyrethroid. PLOS ONE 2011, 6(9):e24968.

178. N'Guessan R, Asidi A, Boko P, Odjo A, Akogbéto M, Pigeon O, Rowland M: An experimental hut evaluation of PermaNet 3.0, a deltamethrin-pyperonyl butoxide combination net, against pyrethroid-resistant Anopheles gambiae and Culex quinquefasciatus mosquitoes in southern Benin. T Roy Soc Trop Med H 2010, 104:758-765.

doi:10.1186/1756-3305-7-450

Cite this article as: Silva et al:: Mutations in the voltage-gated sodium channel gene of anophelines and their association with resistance to pyrethroids - a review. Parasites \& Vectors 2014 7:450

\section{Submit your next manuscript to BioMed Central and take full advantage of:}

- Convenient online submission

- Thorough peer review

- No space constraints or color figure charges

- Immediate publication on acceptance

- Inclusion in PubMed, CAS, Scopus and Google Scholar

- Research which is freely available for redistribution 